\title{
EPIDEMIOLOGY OF TRAUMATIC INJURIES OF THE UPPER LIMBS IN A UNIVERSITY HOSPITAL
}

\section{EPIDEMIOLOGIA DAS LESÕES TRAUMÁTICAS DO MEMBRO SUPERIOR EM HOSPITAL UNIVERSITÁRIO}

\author{
Samuel Ribak ${ }^{1,2}$, Elton João Nunes de Oliveira ${ }^{1,2}$, Gustavo Pupo Rosolino ${ }^{1}$, Pedro Orru Neto $^{1}$, Alexandre Tietzmann ${ }^{1}$ \\ 1. Pontifícia Universidade Católica de Campinas, Campinas, SP, Brazil. \\ 2. Hospital Nossa Senhora do Pari, São Paulo, SP, Brazil.
}

\section{ABSTRACT}

Objective: To evaluate the epidemiology of traumatic injuries of the upper limbs treated at a university hospital and identify the causes, types of injuries, and risk factors. Methods: A prospective study was performed with accidents resulting in trauma categorized into three groups: domestic, occupational, or transportation-related. A questionnaire containing information about the patient and the accident was administered. Lesion characteristics were evaluated according to the injured area, the type of injury, and the management strategy adopted for each case. Results: A total of 613 patients were evaluated. The most frequent accidents were domestic (66.6\%), predominantly involving men (67.9\%) with a mean age of 31 years. Wrist lesions prevailed in transportation-related (31.1\%) and domestic (29.6\%) accidents, and in accidents involving fingers at work (54.2\%). Closed fractures were more frequent and conservative treatment was indicated most often. Serious injuries were associated with finger accidents (39.4\%). There was a correlation between the level of education and the type of accident. Conclusion: Traumatic injuries of the upper limbs were more frequent in domestic accidents and in male patients. Closed fractures were the most common type of fracture and were usually treated conservatively. Serious injuries were more often related to finger trauma. Education level influenced domestic, transportation-related, and occupational accidents. Level of Evidence IV, Case Series.

Keywords: Accidents, Occupational; Trauma; Epidemiology; Upper extremity; Hand; Risk factors; Incidence.

\section{RESUMO}

Objetivo: Realizar a epidemiologia das lesões traumáticas dos membros superiores, atendidas em Hospital Universitário, identificando sua origem e tipos de lesões, determinando fatores de riscos. Métodos: É um estudo prospectivo onde os acidentes foram caracterizados em três grupos: doméstico, trabalho ou transporte. Um questionário contendo informações pessoais e do acidente foi aplicado. Avaliaram-se as características da lesão referente ao seguimento afetado, tipo de lesão e conduta adotada para cada caso. Resultados: Avaliou-se 613 pacientes; os acidentes mais frequentes foram domésticos (66,6\%), predominando o sexo masculino (67,9\%), com média de idade 31 anos. As lesões em punhos prevaleceram nos acidentes de transporte (31,1\%) e domésticos (29,6\%). Nos acidentes de trabalho, lesões de dedos (54,2\%). A fratura fechada foi mais recorrente e o tratamento conservador o mais indicado. As lesões graves relacionaram-se à acidentes em dedos (39,4\%). Houve correlação entre nível de escolaridade e tipos de acidentes. Conclusão: Lesões traumáticas dos membros superiores são mais incidentes em acidentes domésticos e em pacientes do sexo masculino. A fratura fechada é a mais frequente e o tratamento conservador o mais indicado. As lesões graves são relacionadas a acidentes em dedos. A escolaridade apresenta diferença em relação a acidentes doméstico, de transporte ou de trabalho. Nível de evidência IV, série de casos.

Descritores: Acidentes de trabalho. Trauma. Epidemiologia. Membro superior. Mão. Fatores de risco. Incidência.

Citation: Ribak S, Oliveira EJN, Rosolino GP, Orru Neto P, Tietzmann Al. Epidemiology of traumatic injuries of the upper limbs in a university hospital. Acta Ortop Bras. [online]. 2018;26(6):370-3. Available from URL: http://www.scielo.br/aob.

\section{INTRODUCTION}

Traumatic injuries of the upper limbs are responsible for a large number of patients who require care by emergency services. In addition to the impact of these lesions on patient health and daily life, they impose a significant economic burden on the community. ${ }^{1}$ Studies related to occupational accidents show that hand injuries lead to permanent disability in about $50 \%$ of cases, with a high percentage of patients unable to return to work, for example, in cases with ulnar and median nerve injury (24\%) and in patients with finger amputations (36\%). ${ }^{2}$

In 2011, among the 50 International Classification of Diseases (ICD) codes with a higher incidence of work-related injuries, wrist and hand injuries (S61) were the most frequent, representing $10.1 \%$ of the total. ${ }^{3}$

All authors declare no potential conflict of interest related to this article. 
Performing unusual tasks, distraction, fatigue, performing activities with haste, use of malfunctioning equipment or tools, new work activities, and not using personal protective equipment (PPE) are associated with the occurrence of acute lesions in the upper limbs. ${ }^{4}$ The need for prevention has been emphasized especially in relation to the identification and control of risk factors. ${ }^{5}$

Accordingly, an update of the epidemiology of traumatic upper limb injuries would reinforce the need for ongoing development of preventive methods in order to avoid or minimize damage caused by accidents, since these have great physical, functional, and emotional impacts on the individual and the community.

The objective of this study was to perform an epidemiological assessment of patients with traumatic injuries of the upper limbs presenting to a University Hospital, to identify the cause and type of injuries, and to determine the risk factors.

\section{MATERIALS AND METHODS}

This prospective study was performed at a teaching hospital in a large urban center. The project was approved by the Ethics Committee of the Plataforma Brasil (CAAE 54547716.2.0000.5435, registered under number 1.473.589) and all patients signed an informed consent form. All patients in primary care with traumatic injuries of the upper limbs (fingers, hand, wrist, forearm, elbow, arm, and shoulder) treated in the emergency room by the Orthopedic Service between April and September 2016 were included in the study. Patients with injuries treated by other services, those with chronic injuries, and patients who refused to participate in the study were excluded.

The accidents were characterized into three groups based on origin: domestic, occupational (or work-related), or transportation-related (only related to a means of transportation).

A questionnaire was administered in a standardized manner by resident physicians of the service, collecting the information provided by the patient or by the responsible parent/caregiver.

The questionnaire contained personal information, including sex, age, occupational activity, education; information about the accident, including place of occurrence, day of the week, time of the day, alcohol consumption, use of PPE; employment status (self-employed, contract worker, temporary, service provider); and time of the day (beginning, middle, end).

The characteristics of the lesions were assessed with reference to specific follow-up; the type of lesion was described, with details about the affected structures and the management strategy adopted for each case. Severe lesions were characterized as having one of the following characteristics: exposed fracture, amputation, neurotendinous lesions, or surgical treatment.

The statistical methodology ${ }^{6}$ used was analysis of variance, which compares the means using the variance. The Equality Test of two proportions was used to compare whether the proportion of responses of two given variables and/or their levels were statistically significant. The chi-square test assessed whether two variables and their levels exhibited statistical dependence (association). The confidence interval $(\mathrm{Cl})$ for the mean determined the probability of confidence. The tests were performed with a significance level of $5 \%$ and $95 \% \mathrm{Cl}$.

\section{RESULTS}

Data were obtained from 613 patients. The most frequent accidents were domestic (66.6\%), followed by transportation-related (20.6\%), and occupational (12.8\%) accidents (Figure 1); there was a statistically significant difference in the frequency of domestic accidents in comparison to the others $(p<0.001)$.
Overall, $67.9 \%$ of patients were male and there was a statistically significant difference between the three groups $(p<0.001)$ (Figure 2$)$. The mean age was 31 years for cases involving domestic accidents (range: 1-97), 39.6 years (range: 16-64) for those involving occupational accidents, and 28.9 years (range $3-84$ ) for those involving transportation-related accidents (Figure 3).

When assessing the occurrence of accidents in terms of the time and day, 30\% occurred in the afternoon, at the beginning of the week (Monday and Tuesday); on other days, there was a higher prevalence of accidents at night. There was also an increase in the percentage of accidents occurring on weekends (Friday, Saturday, and Sunday) (Table 1). There was no statistically significant correlation between the accidents occurring between different periods of the day or on specific days of the week.

With regard to the distribution of the injured upper limb segment by each group, there was a prevalence of wrist injuries in the transportation-related group (31.1\%) and the domestic accidents group (29.6\%); however, in cases involving occupational accidents, finger injuries were the most prevalent (54.2\%) (Table 2).

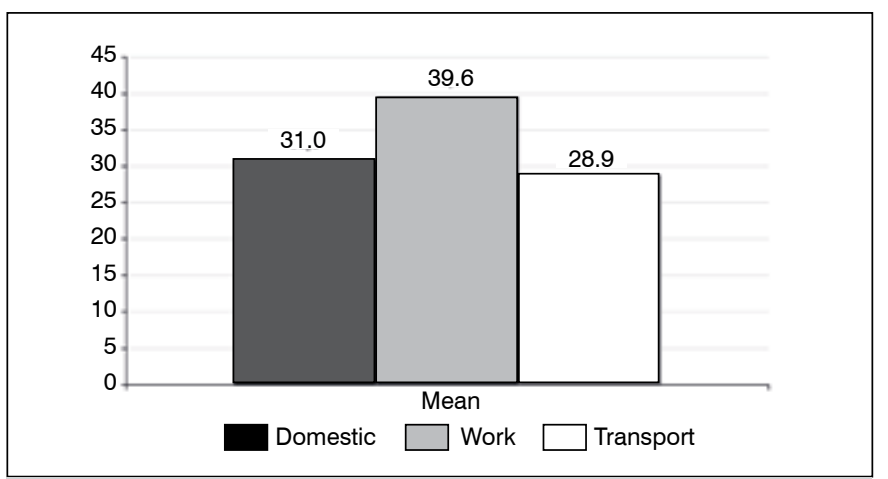

Figure 1. Distribution of patients according to the type of accident.

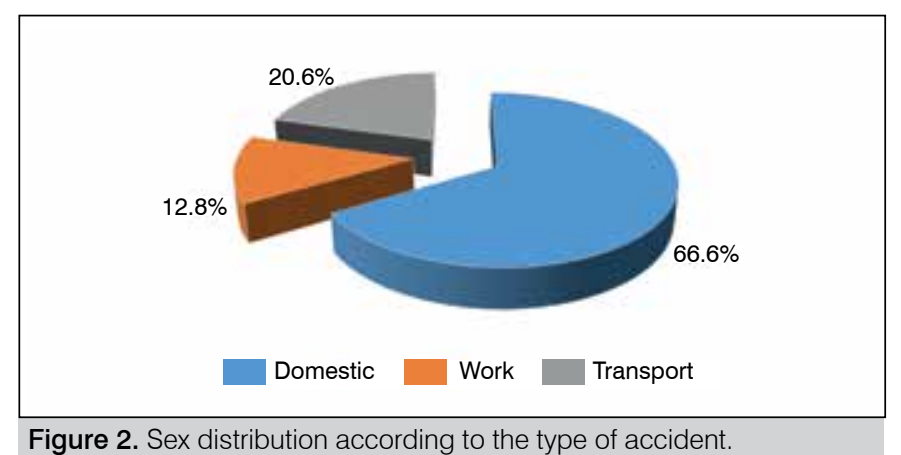

Figure 2. Sex distribution according to the type of accident.

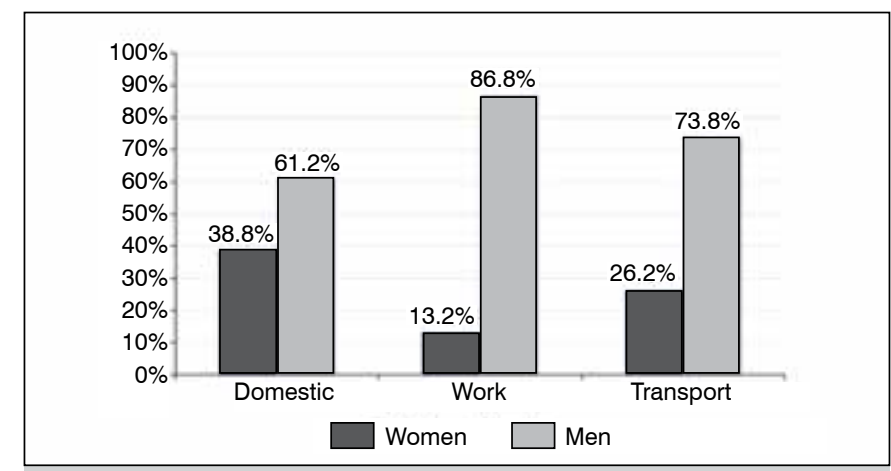

Figure 3. Mean age according to the type of accident. 
A closed fracture was the most frequently recurring lesion type across all three groups, while finger-related injuries were significantly more frequent $(86.7 \%)$ in transportation-related accidents compared to the other groups $(p<0.001)$ (Table 3$)$.

Regarding the management strategy adopted, conservative treatment was the most frequently used (Table 4), and was significantly more common compared to other forms of treatment $(p<0.001)$. Severe lesions associated with finger accidents (39.4\%) (i.e., fracture, amputation, neurotendinous lesions, or surgical treatment), showed the highest statistical significance in terms of incidence $(p<0.001)$ (Table 5).

There was no correlation between any accident group and alcoho consumption, which makes this variable neutral. With regard to education, there was a significant difference in the number of domestic accidents among illiterate patients (20\%, p < 0.001), in the number of occupational accidents among patients with primary school education $(51 \%, p<0.001)$, and in the number of transportation-related accidents among patients with secondary school education $(42 \%, p<0.001)$. In patients with higher education, there was no significant difference between the groups (Table 6). By examining the group of occupational accidents in detail, there was no statistical correlation between the use of PPE and the labor market conditions; the same was observed with regard to the severity of lesions.

Table 1. Occurrence of accidents according to time period and weekday

\begin{tabular}{c|c|c|c|c|c|c|c|c}
\hline & \multicolumn{2}{|c|}{ Morning } & \multicolumn{2}{c|}{ Afternoon } & \multicolumn{2}{c|}{ Night } & \multicolumn{2}{c}{ Total } \\
\hline & $\mathbf{N}$ & $\%$ & $\mathbf{N}$ & $\%$ & $\mathbf{N}$ & $\%$ & $\mathbf{N}$ & $\%$ \\
\hline $\begin{array}{c}\text { Beginning of } \\
\text { the week }\end{array}$ & 44 & $27 \%$ & 78 & $30 \%$ & 39 & $22 \%$ & 161 & $27 \%$ \\
\hline $\begin{array}{c}\text { Middle of the } \\
\text { week }\end{array}$ & 47 & $28 \%$ & 72 & $28 \%$ & 53 & $30 \%$ & 172 & $29 \%$ \\
\hline Weekend & 74 & $45 \%$ & 111 & $43 \%$ & 84 & $48 \%$ & 269 & $45 \%$ \\
\hline Total & 165 & $27 \%$ & 261 & $43 \%$ & 176 & $29 \%$ & 602 & $100 \%$ \\
\hline
\end{tabular}

Table 2. Distribution of affected region according to accident group

\begin{tabular}{c|c|c|c|c|c|c}
\hline \multirow{2}{*}{$\begin{array}{c}\text { Affected } \\
\text { segment }\end{array}$} & \multicolumn{2}{|c|}{ Domestic } & \multicolumn{2}{c|}{ Work } & \multicolumn{2}{c}{ Transport } \\
\cline { 2 - 7 } & $\mathbf{N}$ & $\%$ & $\mathbf{N}$ & $\%$ & $\mathbf{N}$ & $\%$ \\
\hline Shoulder & 43 & $10.4 \%$ & 5 & $6.0 \%$ & 27 & $20.0 \%$ \\
\hline Arm & 18 & $4.4 \%$ & 1 & $1.2 \%$ & 11 & $8.1 \%$ \\
\hline Elbow & 49 & $11.9 \%$ & 2 & $2.4 \%$ & 9 & $6.7 \%$ \\
\hline Forearm & 47 & $11.4 \%$ & 2 & $2.4 \%$ & 13 & $9.6 \%$ \\
\hline Wrist & 122 & $29.6 \%$ & 14 & $16.9 \%$ & 42 & $31.1 \%$ \\
\hline Hand & 61 & $14.8 \%$ & 15 & $18.1 \%$ & 16 & $11.9 \%$ \\
\hline Fingers & 67 & $16.3 \%$ & 45 & $54.2 \%$ & 20 & $14.8 \%$ \\
\hline Multiple injuries & 5 & $1,2 \%$ & 1 & $1.2 \%$ & 3 & $2.2 \%$ \\
\hline Total & 412 & & 83 & & 135 & \\
\hline
\end{tabular}

\begin{tabular}{c|c|c|c|c|c|c}
\multicolumn{2}{c}{ Table 3. Distribution of lesions according to accident group. } \\
\hline $\begin{array}{c}\text { Tipo de } \\
\text { Ferimento }\end{array}$ & \multicolumn{2}{|c|}{ Domestic } & \multicolumn{2}{|c}{ Work } & \multicolumn{2}{c}{ Transport } \\
\cline { 2 - 7 } & $\mathbf{N}$ & $\%$ & $\mathbf{N}$ & $\%$ & $\mathbf{N}$ & $\%$ \\
\hline Closed fracture & 300 & $72.8 \%$ & 41 & $49.4 \%$ & 117 & $86.7 \%$ \\
\hline Open fracture & 27 & $6.6 \%$ & 17 & $20.5 \%$ & 10 & $7.4 \%$ \\
\hline $\begin{array}{c}\text { Laceration/ } \\
\text { Perforation/Cut }\end{array}$ & 17 & $4.1 \%$ & 10 & $12.0 \%$ & 3 & $2.2 \%$ \\
\hline Tendon lesion & 21 & $5.1 \%$ & 8 & $9.6 \%$ & 1 & $0.7 \%$ \\
\hline Neurologic lesion & 4 & $1.0 \%$ & 0 & $0.0 \%$ & 1 & $0.7 \%$ \\
\hline Vascular lesion & 1 & $0.2 \%$ & 0 & $0.0 \%$ & 0 & $0.0 \%$ \\
\hline Dislocation & 43 & $10.4 \%$ & 5 & $6.0 \%$ & 10 & $7.4 \%$ \\
\hline Amputation & 3 & $0.7 \%$ & 4 & $4.8 \%$ & 0 & $0.0 \%$ \\
\hline Complex injury & 0 & $0.0 \%$ & 2 & $2.4 \%$ & 0 & $0.0 \%$ \\
\hline Total & 412 & & 83 & & 135 & \\
\hline
\end{tabular}

Table 4. Distribution of management according to accident group.

\begin{tabular}{c|c|c|c|c|c|c}
\hline \multirow{2}{*}{ Management } & \multicolumn{2}{|c|}{ Domestic } & \multicolumn{2}{c|}{ Work } & \multicolumn{2}{c}{ Transport } \\
\cline { 2 - 7 } & $\mathbf{N}$ & $\%$ & $\mathbf{N}$ & $\%$ & $\mathbf{N}$ & $\%$ \\
\hline $\begin{array}{c}\text { Treatment } \\
\text { conservative }\end{array}$ & 329 & $79.9 \%$ & 49 & $59.0 \%$ & 104 & $77.0 \%$ \\
\hline Surgical treatment & 77 & $18.7 \%$ & 32 & $38.6 \%$ & 29 & $21.5 \%$ \\
\hline Inpatient & 0 & $0,0 \%$ & 0 & $0.0 \%$ & 1 & $0.7 \%$ \\
\hline Avoidance & 1 & $0.2 \%$ & 0 & $0.0 \%$ & 0 & $0.0 \%$ \\
\hline No response & 1 & $0.2 \%$ & 0 & $0.0 \%$ & 0 & $0.0 \%$ \\
\hline Total & 412 & & 83 & & 135 & \\
\hline
\end{tabular}

\begin{tabular}{c|c|c|c}
\multicolumn{4}{c}{ Table 5. Distribution of affected segment according to severity. } \\
\hline Follow-up & $\mathbf{N}$ & $\%$ & P value \\
\hline Fingers & 67 & $39.4 \%$ & $<0.0001$ \\
\hline Wrist & 34 & $20.0 \%$ & $<0.0001$ \\
\hline Hand & 20 & $11.8 \%$ & $<0.0001$ \\
\hline Elbow & 13 & $7.6 \%$ & $<0.0001$ \\
\hline Forearm & 13 & $7.6 \%$ & $<0.0001$ \\
\hline Arm & 12 & $7.1 \%$ & $<0.0001$ \\
\hline Shoulder & 6 & $3.5 \%$ & $<0.0001$ \\
\hline Multiple injuries & 5 & $2.9 \%$ & $<0.0001$ \\
\hline Total & 170 & &
\end{tabular}

Table 6. Correlation of accident groups with alcohol consumption and level of education.

\begin{tabular}{|c|c|c|c|c|c|c|c|c|c|c|}
\hline & & \multicolumn{2}{|c|}{ Domestic } & \multicolumn{2}{|c|}{ Work } & \multicolumn{2}{|c|}{ Transport } & \multicolumn{2}{|c|}{ Total } & \multirow{2}{*}{$P$ value } \\
\hline & & $\mathrm{N}$ & $\%$ & N & $\%$ & $\mathrm{~N}$ & $\%$ & N & $\%$ & \\
\hline \multirow{2}{*}{ Alcohol } & Yes & 350 & $89 \%$ & 73 & $96 \%$ & 106 & $87 \%$ & 529 & $90 \%$ & \multirow{3}{*}{0.110} \\
\hline & No & 42 & $11 \%$ & 3 & $4 \%$ & 16 & $13 \%$ & 61 & $10 \%$ & \\
\hline \multirow{4}{*}{ Education } & Illiterate & 77 & $20 \%$ & 3 & $4 \%$ & 7 & $6 \%$ & 87 & $15 \%$ & \\
\hline & Primary & 182 & $48 \%$ & 37 & $51 \%$ & 54 & $46 \%$ & 273 & $48 \%$ & \multirow{3}{*}{$<0.001$} \\
\hline & Secondary & 106 & $28 \%$ & 29 & $40 \%$ & 50 & $42 \%$ & 185 & $32 \%$ & \\
\hline & Higher & 14 & $4 \%$ & 4 & $5 \%$ & 7 & $6 \%$ & 25 & $4 \%$ & \\
\hline
\end{tabular}

\section{DISCUSSION}

The upper limbs are indispensable for interaction with the external environment and are essential for the expression of individuality; thus, upper limb lesions can cause significant psychosocial and economic damage.

Three groups were considered to investigate the epidemiological aspects of accidents involving the upper limbs: domestic, transportation-related, and occupation-related causes. This was because the critical analysis of each group was necessary to evaluate the characteristics regarding the mechanisms of injury, place of occurrence, and severity of trauma.

In our series, domestic accidents were responsible for the majority of lesions encountered (66.6\%). This incidence is similar to data reported by Frazier et al. ${ }^{7}$ and by Chung et al. ${ }^{8}$, in which $50 \%$ of injuries and $30 \%$ of trauma injuries occurred in a domestic environment, respectively. In the literature, between $62.9 \%$ and $66 \% \%, 79$ of injuries were reported to occur in men, which is similar to the $67.9 \%$ reported in this study. This finding would indicate the occurrence of a higher number of hospital visits due to occupational accidents and domestic accidents, in both men and women.

The stratification of samples by average age confirms the greater concentration of accidents in economically-active patients, i.e., those aged between 28.9 and 39.6 years, in the three groups studied; this reflects a social and economic burden. ${ }^{7,9,10,11}$ 
Our sample revealed a higher percentage of accidents occurring at night and in the evening, unlike the data reported by Lombardi et al. ${ }^{9}$, who reported a predominance of accidents in the morning. When considering the days of the week, there were a higher number of accidents on weekends; however, the current literature cites a uniform occurrence of accidents across all days of the week. ${ }^{9,12} \mathrm{It}$ is assumed that factors, such as doubling of working hours, fatigue, and distraction may be responsible for such occurrences.

Lesions of the wrist were the most prevalent in this study, when taking into account transportation-related (31.1\%) and domestic accidents (29.6\%), which is in concordance with Chung et al. ${ }^{8}$ and Fonseca et al. ${ }^{11}$. However, Larsen et al. ${ }^{13}$ describe a higher incidence of hand involvement among accidents. In cases of work-related accidents, there is a higher incidence of finger injuries reported in the literature, which is similar to that determined in our study $(54.2 \%),{ }^{7,9,11,13}$

With respect to the type of lesion, closed fractures unexpectedly displayed the highest incidence in all groups. In contrast, published data indicates lacerations to the hands as the main injury. ${ }^{7,9,14,15}$ In our study, lacerations were among the least frequently observed type of lesions. When we take into account the severity of the lesions, the fingers were the most affected (39.4\%) and mainly occurred in cases involving occupational accidents, ${ }^{10,14}$ which can be attributed to the proximity of the anatomical structures in the hand, which are more likely to undergo complex injuries.

With respect to the clinical management adopted for the three groups of accidents, conservative treatment was the most frequently used, suggesting that many of the accidents were related to low-energy impact, causing less severe lesions; nevertheless, these generate high costs to the health system and social welfare. ${ }^{8}$ Few studies have assessed the relationship between alcohol consumption and domestic and occupational accidents. In the present study, only $10 \%$ of the accidents reported alcohol use. These statistics demonstrate the difficulty of conducting research in this area using questionnaires, as we must take into consideration eventual biases in the individual's responses, which are influenced by fear, insecurity, and the potential legal implications involved in the use of alcohol. Therefore, it is possible that information regarding alcohol use may have been intentionally omitted by patients.
In general, studies that assessed the relationship between education and types of accidents were not available in the literature. It is interesting to note the significant differences associated with illiterate patients in domestic accidents, patients with primary education in work-related accidents, and patients with secondary education in transportation accidents. Notably, in patients with higher education, there were no such differences, suggesting that improvement in education levels may lead to a reduction of the incidence of accidents in the different groups.

In this study, there was no correlation between the use of PPE and the severity of the lesions. Jin et al. ${ }^{4}$ correlated the use of gloves with severe injuries. This indicates that some equipment does not protect the worker from high-energy accidents; thus, we believe that it is important to prioritize awareness regarding precautionary measures during work activities in order to minimize accident risks. As a whole, this study stresses that the prevention of upper limb injuries requires multiple approaches, such as greater caution during everyday activities, especially at home. Attention should be given to activities in the evenings, at night, and on weekends. Proper maintenance of work equipment with suitable instructions with regard to handling, the adequacy of domestic environments (i.e., safety bars, nonslip floors), and caution in handling of sharp objects, require investments for the creation of projects and intervention strategies involving multidisciplinary teams to foster an increased awareness regarding the functional consequences that may arise from lesions of the upper limbs, as well as their socioeconomic impact.

\section{CONCLUSIONS}

The incidence of traumatic injuries of the upper limbs was found to be higher in domestic accidents and in male patients, regardless of the type of accident (domestic, transportation-relatred, or occupational). Closed fractures were the most frequent in cases of transportation accidents, and conservative treatment was the most suitable management strategy for any type of accident. The injuries with greater severity were associated with accidents involving fingers. The incidence of domestic, transportation-related, or occupational accidents were different according to education levels.

AUTHORS' CONTRIBUTIONS: Each author contributed individually and significantly to the drafting of the manuscript. SR (0000-0003-0345-3921)*, EJNO $(0000-0002-1530-976 X)^{\star}$ and AT (0000-0002-1952-2277) ${ }^{\star}$ were the main contributors in the drafting of the manuscript. GPR (0000-0002-2013-1417) ${ }^{\star}$ and PO (0000-0001-7693-3606)* performed data collection and completion of questionnaires, followed the patients, and gathered clinical data. EJNO, PO, and SR evaluated the statistical analysis. SR, EJNO, AT, and GPR performed bibliographic search and revision of the manuscript and contributed to the intellectual concept of the study. *ORCID (Open Researcher and Contributor ID).

\section{REFERENCES}

1. Polinder S, lordens GI, Panneman MJ, Eygendaal D, Patka P, Den Hartog D, et al. Trends in incidence and costs of injuries to the shoulder, arm and wrist in The Netherlands between 1986 and 2008. BMC Public Health. 2013;13:531.

2. Gustafsson M, Ahlström G. Problems experienced during the first year of an acute traumatic hand injury - a prospective study. J Clin Nurs, 2004;13(8):986-95.

3. Anuário Estatístico da Previdência Social/Ministério da Previdência Social, Empresa de Tecnologia e Informações da Previdência Social, vol 22. Brasília: MPS/DATAPREV, 2013.

4. Jin K, Lombardi DA, Courtney TK, Sorock GS, Li M, Pan R, et al. A case-crossover study of work-related acute traumatic hand injuries in the People's Republic of China. Scand J Work Environ Health. 2012;38(2):163-70.

5. Souza APS, Cabral LHA, Sampaio RF, Mancini MC. Acidentes de trabalho envolvendo mãos: casos atendidos em um serviço de reabilitação. Fisioter Pesqui. 2008;15(1):64-71.

6. Kirkwood BR, Strerne JAC. Essential medical statistics. 2nd ed. Massachusetts, USA: Blackwell Science; 2006. p.502.

7. Frazier WH, Miller M, Fox RS, Brand D, Finseth F. Hand injuries: incidence and epidemiology in an emergency service. JACEP. 1978;7(7):265-8.
8. Chung KC, Spilson SV, Arbor A. The frequency and epidemiology of hand and forearm fractures in the United States. J Hand Surg Am. 2001;26(5):908-15.

9. Lombardi DA, Sorock GS, Hauser R, Nasca PC, Eisen EA, Herrick RF, et al. Temporal factors and the prevalence of transient exposures at the time of an occupational traumatic hand injury. J Occup Environ Med. 2003;45(8):832-40.

10. Angermann P, Lohmann M. Injuries to the hand and wrist. A Study Of 50,272 Injuries. J Hand Surg Br. 1993;18(5):642-4.

11. Fonseca MCR, Mazzer N, Barbieri CH, Elui VMC. Traumas da mão: estudo retrospectivo. Rev Bras Ortop. 2006;41(5):181-6.

12. Chow CY, Lee $H$, Lau J, Yu ITS. Transient risk factors for acute traumatic hand injuries: a case-crossover study in Hong Kong. Occup Environ Med. 2007;64(1):47-52.

13. Larsen CF, Mulder S, Johansen AM, Stam C. The epidemiology of hand injuries in the Netherlands and Denmark. Eur J Epidemiol. 2004;19(4):323-7.

14. Sorock GS, Lombardi DA, Hauser RB, Eisen EA, Herrick RF, Mittleman MA. Acute traumatic occupational hand injuries: Type, location and severity. J Occup Environ Med. 2002;44(4):345-51.

15. Edwards DH. The spectrum of hand injuries. The Hand. 1975;7(1):46-50. 